\title{
Bio-Monitoring of Mangal Sediments and Tissues for Heavy Metal Accumulation in the Mangrove Forest of Cross River Estuary
}

\author{
${ }^{1}$ E.A.B. Edu, ${ }^{2}$ N.L. Edwin-Wosu and ${ }^{1}$ A. Inegbedion \\ ${ }^{1}$ Department of Botany, University of Calabar, Calabar, P.M.B. 1115, Nigeria \\ ${ }^{2}$ Department of Plant Science and Biotechnology, University of Port Harcourt, Choba, P.M.B. 5323, \\ Port Harcourt
}

\begin{abstract}
Background: Mangroves are among the most productive intertidal ecosystems on earth. They serve as nursery and breeding grounds for several commercially important species of marine fauna. Despite their economic and ecological importance, they are under threat from over-exploitation and organic and inorganic pollution sources. This has led to their use as bio-indicators for pollution monitoring programmes. Therefore, the need to periodically monitor the Cross River Estuary mangroves for heavy metals pollution should not be overemphasized given the high premium placed on this ecosystem. Objectives: The present study was aimed at evaluating mangrove sediments and tissues for heavy metals accumulation in the different tidal levels of Cross River Estuary which will be an indicator for pollution. Method: Ten random samples of composite surface sediments $(0-5 \mathrm{~cm})$ were collected from low, mid and high tidal levels using a modified Van Veen $\left(0.1 \mathrm{~m}^{2}\right)$ grab sampler. Also samples of senescent leaves, barks and roots of randomly selected ten individual plants of Nypa fruticans (low tide), Rhizophora racemosa (mid tide) and Avicennia africana (high tide) were also collected for heavy metal analyses during the year 2011. Result: The results showed that there were significant variations $(\mathrm{p}<0.05)$ in heavy metals deposition across the tidal levels. In the mangrove sediments, iron (Fe) content (415.8 $\mathrm{mg} \mathrm{g}^{-1}$ dry weight) was highest in the high tidal level where $A$. africana was predominantly sampled while $N$. fruticans (low tide) had the lowest deposition of the metal $\left(304.4 \mathrm{mg} \mathrm{g}^{-1} \mathrm{dry}\right.$ weight). The accumulation of heavy metals in the mangrove tissues took the general trend of root $>$ bark $>$ leaves, the mangrove notwithstanding. It was also observed that cadmium deposition in sediments was comparatively higher than RSV indicating possible cadmium pollution. Generally, accumulation of heavy metals in the mangrove forest of Cross River estuary was within permissible limits. Conclusion: Although the concentrations obtained for the heavy metals studied are generally below documented toxic levels, however, the increasing level of urbanization and industrialization in Calabar municipality and its environs calls for continuous vigilance, surveillance and monitoring of this sensitive and all important ecosystem to protect and ensure that heavy metal pollution is minimal.
\end{abstract}

Key words: Cross River, Rhizophora racemosa, Avicennia africana, Nypa fruticans, halophyte

Insight Ecology 4 (1): 46-52, 2015

\section{INTRODUCTION}

Mangroves are halophytic trees that dominate the intertidal zone along coastlines, estuaries and islands in tropical and sub-tropical regions of the world where they exist under conditions of high salinity, extreme tides, strong winds, high temperature with muddy and anaerobic soil $^{1,2}$. They thrive in tropical estuaries which receive evenly distributed heavy rainfall throughout the year. Mangroves are among the most productive

Corresponding Author: E.A.B. Edu, Department of Botany, University of Calabar, Calabar, P.M.B 1115, Nigeria intertidal ecosystems on earth ${ }^{3,4}$. They serve as nursery and breeding grounds for several commercially important species of marine fauna.

However, in spite of their economic and ecological importance, mangrove forests are under threat from over-exploitation, destruction and pollution with heavy metals and petroleum ${ }^{5-8}$. Mangrove ecosystems serve as sink for the deposition of heavy metals from anthropogenic sources such as domestic, industrial and agricultural discharges 9 . This has led to their use as bio-indicators for pollution monitoring programmes as well as in phyto-infiltration and phyto-extraction technology ${ }^{10}$. 
These pollutants become trapped in mangrove sediments and eventually become partly locked up in detrital particles, making them potentially bio-available to detrital feeders ${ }^{11-13}$. Undoubtedly, they also become accumulated in tissues of these organisms leading to their amplification through bio-accumulation along the food chain. The cycling of heavy metals because of their toxicity, bio-accumulation capacity and persistence, is a serious question being addressed by many studies on mangrove environments ${ }^{14-15}$. Filip ${ }^{16}$, Ramasamy and Murugan $^{17}$ observed that heavy metal-mediated pollution affect the development and biochemical activities of soil microorganisms which might directly or/and indirectly elicit toxic influence on other flora and fauna species in the ecosystem.

The monitoring of mangrove ecosystems for heavy metal pollution become imperative given the high premium placed on this economic and ecological important ecosystem. Recently, the upsurge of human activities along the Great Kwa Basin, urbanization and industrialization, uncontrolled and mismanagement of open dumpsters in Cross River State, Nigeria has ignited severe panic for eco-toxicologists, especially as it concerns heavy metal pollution. This study is aimed at evaluating the extent of using heavy metal pollution bio-indicators on the mangrove sediments and tissues of bioindicator.

\section{MATERIALS AND METHODS}

Description of study area: The research was undertaken in 2011 spanning January to December. The study area covered the mangrove forests of the Great Kwa River, East of the Cross River Estuary which flows into the Gulf of Guinea. This area lies within latitudes $04^{\circ} 45$ and $04^{\circ} 15$ North of the Equator and longitudes $008^{\circ} 15$ and $008^{\circ} 30$ East of Greenwich Meridian along the eastern border of the University of Calabar, Nigeria.

Sampling methods: Ten random samples of composite surface sediments $(0-5 \mathrm{~cm})$ were collected from low, mid and high tidal levels using a modified Van Veen $\left(0.1 \mathrm{~m}^{2}\right)$ grab sampler. Samples of senescent leaves, barks and roots of randomly selected ten individual plants of Nypa fruticans, Rhizophora racemosa and Avicennia africana were also collected for heavy metal analyses. It should be clearly noted that in the Great Kwa River estuary, $N$. fruticans is predominantly found in low tidal level while $R$. racemosa and $A$. africana are found in the mid and high tidal levels, respectively.

Sample preparation and heavy metal analysis: The tissue samples were rinsed with de-ionized water, placed in black polyethylene bags, tagged and stored in cool boxes at $-4^{\circ} \mathrm{C}$ to avoid oxidation. Sediments and plant tissue samples were then oven-dried at $80^{\circ} \mathrm{C}$ to constant weight. The dry samples were ground and sieved through a $250 \mu \mathrm{m}$ mesh screen. $1 \mathrm{~g}$ of each sample was digested in Kjeldahl Digester using a mixture of concentrated $\mathrm{HNO}_{3}$ and $\mathrm{HCl}^{18}$. The digested samples were analyzed for heavy metals (Iron ( $\mathrm{Fe}$ ), manganese $(\mathrm{Mn})$, cadmium $(\mathrm{Cd})$, chromium $(\mathrm{Cr})$, copper $(\mathrm{Cu})$, zinc $(\mathrm{Zn})$, nickel $(\mathrm{Ni})$ and lead $(\mathrm{Pb})$ by flame atomic absorption spectrophotometry (FAAS) (Perkin Elmer-Model 3030).

Data analysis by ANOVA and LSD: Data collected from the analyses were subjected to analysis of variance (ANOVA) using Predictive Analytics SoftWare (PASW), version 18.0 while significant means were separated using Least Significant Difference Test Statistics (LSD). The results were compared with global average shale and fossil rhine (ASV) concentrations of metal ${ }^{19}$ while Concentration Factor (CF) was calculated using previously described method ${ }^{20}$.

\section{RESULTS}

Heavy metal deposition in the mangrove sediments: There were significant differences $(p<0.05)$ in the deposition and accumulation of heavy metals in the mangrove sediments. In the mangrove sediments, iron (Fe) content ( $415.8 \mathrm{mg} \mathrm{g}^{-1}$ dry weight) was highest in the high tidal level where $A$. africana was predominantly sampled while $N$. fruticans (low tide) had the lowest deposition of the metal $\left(304.4 \mathrm{mg} \mathrm{g}^{-1}\right.$ dry weight). However, there was no significant differences $(\mathrm{p}>0.05)$ observed in zinc $(\mathrm{Zn})$, Nickel $(\mathrm{Ni})$ and chromium (Cr) deposit in the mangrove sediments in the low and high tidal levels. For manganese (Mn), there were no significant variations among the tidal levels. The deposition of cadmium was highest in the low tide inhabiting $N$. fruticans while lead $(\mathrm{Pb})$ and copper $(\mathrm{Cu})$ were observed to be high in the sediment of $R$. racemosa (Mid tide) comparing with the sediments in other tidal levels (Fig. 1).

\section{Heavy metal deposition in the mangrove tissues:} Heavy metals accumulation in the mangrove tissues varied significantly $(\mathrm{p}<0.05)$ across the tidal levels as well as specific to mangrove tissues. Iron $(\mathrm{Fe})$ accumulation was more in the roots of the mangrove, the species notwithstanding but however, was lowest on the bark of $R$. racemosa (mid tide). For manganese, its 


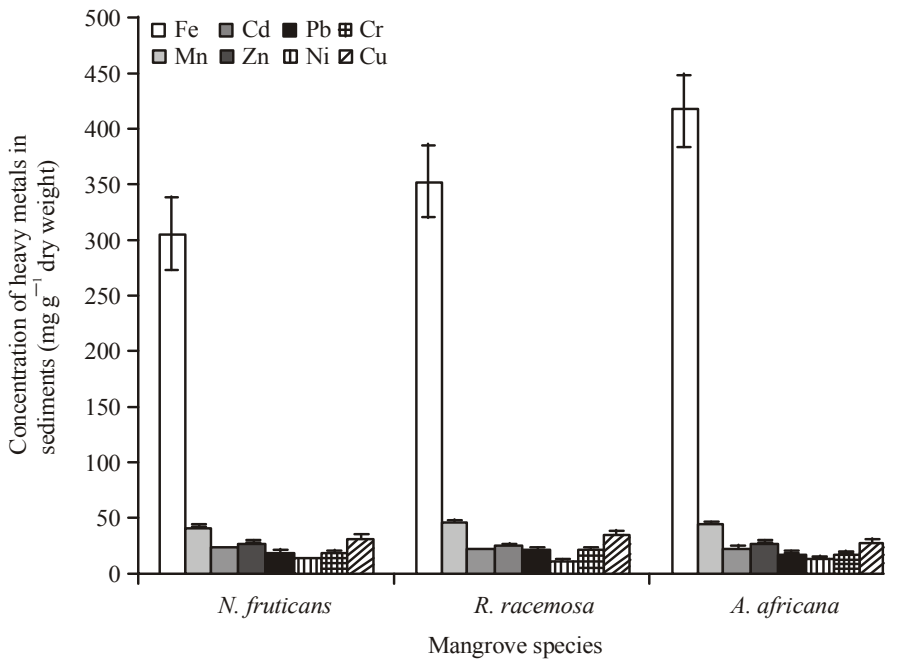

Fig. 1: Concentration heavy metals in the mangrove sediments

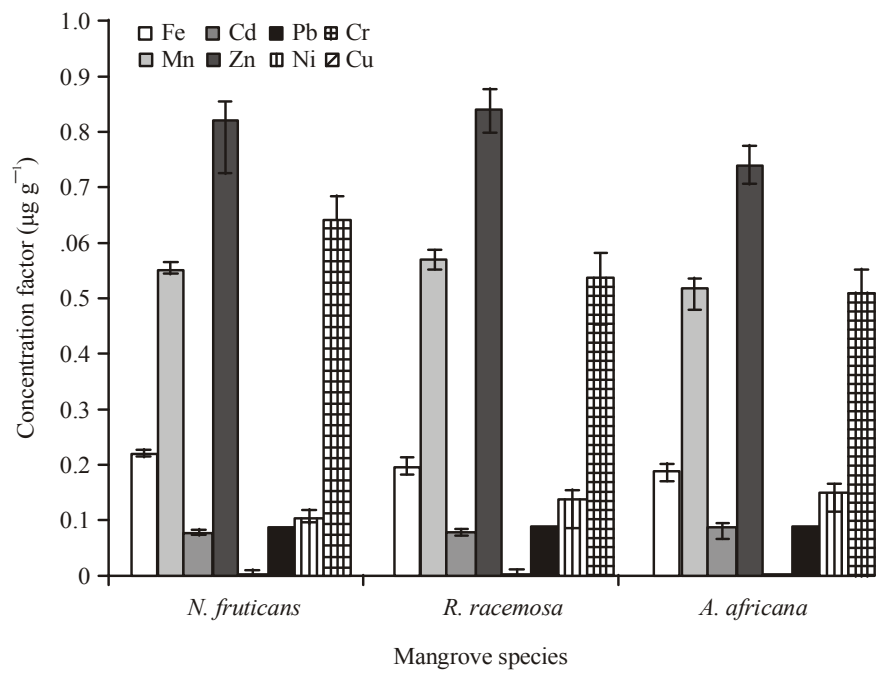

Fig. 2: Concentration factor for heavy metals in the mangrove sediment and plant tissues

accumulation in the roots of $A$. africana (high tide) was the same with that of the bark of $R$. racemosa while its deposition in the leaves of $N$. fruticans was significantly higher than the leaves of $R$. racemosa and $A$. africana, respectively. The bark of $A$. africana accumulated more cadmium. However, other mangrove tissues showed no significant differences, except the leaves of $N$. fruticans and $R$. racemosa.

Accumulation of zinc was high in the bark of A. africana when compared with other tissue parts of the different mangroves. For copper, its accumulation was highest in the barks of $N$. fruticans and $A$. africana. Although, there were instances of deviations, the general trend in the deposition and accumulation of heavy metals was sediments $>$ roots $>$ barks $>$ leaves (Table 1).

Additionally, the Average Shale Value (ASV) for the metals was within permissible range except for cadmium, where ASV was lower than its accumulation in the sediments and plant tissues. It was also observed that the Concentration Factor (CF) for zinc ( $\mathrm{Zn}$ ) was in the three tidal levels (Fig. 2). This was followed by copper and manganese. However, the concentration of cadmium was very low comparatively. 
Table 1: Average concentration of heavy metals $\left(\mathrm{mg} \mathrm{g}^{-1}\right.$, dry weight) in plant tissues and sediments of mangrove species in the mangrove forest of Great Kwa River, East of the Cross River Estuary, Nigeria

\begin{tabular}{|c|c|c|c|c|c|c|c|c|}
\hline \multirow{2}{*}{$\begin{array}{l}\text { Mangrove } \\
\text { species }\end{array}$} & \multicolumn{8}{|c|}{ Heavy metal (mg g ${ }^{-1}$ dry weight) } \\
\hline & $\mathrm{Fe}$ & $\mathrm{Mn}$ & $\mathrm{Cd}$ & $\mathrm{Zn}$ & $\mathrm{Pb}$ & $\mathrm{Ni}$ & $\mathrm{Cr}$ & $\mathrm{Cu}$ \\
\hline \multicolumn{9}{|l|}{ N. fruticans } \\
\hline Root & $81.47 \pm 0.46^{c}$ & $24.11 \pm 0.23^{\mathrm{b}}$ & $1.73 \pm 0.32^{\mathrm{b}}$ & $28.02 \pm 1.23^{\mathrm{d}}$ & $0.42 \pm 0.01^{\mathrm{b}}$ & $1.49 \pm 0.02^{\mathrm{b}}$ & $5.17 \pm 0.21^{\mathrm{c}}$ & $15.87 \pm 0.34^{\mathrm{b}}$ \\
\hline Bark & $52.52 \pm 1.21^{\mathrm{a}}$ & $27.25 \pm 0.37^{c}$ & $2.21 \pm 0.32^{\mathrm{b}}$ & $32.61 \pm 0.46^{\mathrm{e}}$ & $0.018 \pm 0.48^{\mathrm{b}}$ & $1.54 \pm 0.37^{\mathrm{b}}$ & $1.66 \pm 0.03^{b}$ & $26.48 \pm 0.25^{\mathrm{d}}$ \\
\hline Leaves & $67.73 \pm 2.02^{b}$ & $19.88 \pm 0.43^{b}$ & $0.83 \pm 0.01^{\mathrm{a}}$ & $11.54 \pm 0.05^{\mathrm{b}}$ & $0.038 \pm 0.001^{\mathrm{b}}$ & $0.84 \pm 0.01^{\mathrm{b}}$ & $0.61 \pm 0.01^{\mathrm{a}}$ & $20.44 \pm 0.78^{c}$ \\
\hline \multicolumn{9}{|l|}{ R. racemosa } \\
\hline Root & $88.78 \pm 1.34^{c}$ & $24.19 \pm 0.38^{\mathrm{b}}$ & $1.77 \pm 0.48^{\mathrm{b}}$ & $25.35 \pm 0.56^{c}$ & $0.11 \pm 0.001^{\mathrm{b}}$ & $1.54 \pm 0.01^{\mathrm{b}}$ & $6.76 \pm 0.04^{\mathrm{d}}$ & $15.88 \pm 0.24^{\mathrm{b}}$ \\
\hline Bark & $64.01 \pm 1.23^{\mathrm{a}}$ & $37.84 \pm 0.76^{\mathrm{d}}$ & $2.20 \pm 0.02^{\mathrm{b}}$ & $29.17 \pm 0.34^{\mathrm{d}}$ & $0.014 \pm 0.0001^{\mathrm{a}}$ & $1.67 \pm 0.01^{\mathrm{b}}$ & $1.58 \pm 0.02^{\mathrm{b}}$ & $21.34 \pm 0.45^{c}$ \\
\hline Leaves & $64.94 \pm 0.78^{b}$ & $19.54 \pm 0.54^{a}$ & $1.32 \pm 0.03^{\mathrm{a}}$ & $11.54 \pm 0.45^{\mathrm{a}}$ & $0.04 \pm 0.001^{\mathrm{b}}$ & $0.66 \pm 0.01^{\mathrm{a}}$ & $0.77 \pm 0.01^{\mathrm{b}}$ & $21.25 \pm 0.32^{c}$ \\
\hline \multicolumn{9}{|l|}{ A. africana } \\
\hline Root & $82.23 \pm 0.32^{c}$ & $32.82 \pm 0.76^{\mathrm{d}}$ & $1.73 \pm 0.85^{\mathrm{b}}$ & $25.12 \pm 0.53^{c}$ & $0.102 \pm 0.001^{\mathrm{b}}$ & $1.63 \pm 0.14^{\mathrm{b}}$ & $6.53 \pm 0.05^{c}$ & $13.27 \pm 0.11^{\mathrm{a}}$ \\
\hline Bark & $81.20 \pm 0.33^{c}$ & $29.52 \pm 0.86^{c}$ & $3.04 \pm 0.23^{c}$ & $29.55 \pm 0.67^{\mathrm{d}}$ & $0.014 \pm 0.001^{\mathrm{a}}$ & $1.56 \pm 0.24^{\mathrm{b}}$ & $1.91 \pm 0.02^{\mathrm{b}}$ & $24.33 \pm 0.07^{\mathrm{d}}$ \\
\hline Leaves & $67.68 \pm 0.35^{\mathrm{b}}$ & $19.67 \pm 0.45^{a}$ & $1.59 \pm 0.46^{\mathrm{b}}$ & $10.81 \pm 0.54^{a}$ & $0.038 \pm 0.002^{b}$ & $0.70 \pm 0.05^{\mathrm{a}}$ & $0.69 \pm 0.001^{a}$ & $21.85 \pm 0.06^{c}$ \\
\hline $\begin{array}{l}\text { Average shale } \\
\text { value (ASV) }\end{array}$ & 4700 & 600 & 1.31 & 45 & 20 & 68 & 83 & 45 \\
\hline
\end{tabular}

\section{DISCUSSION}

Industrial wastes laden with toxic metals are of great concern in the marine ecosystem given that they are not easily degradable, leading to their persistency in the ecosystem. Worst still is the fact that these metals accumulate in different trophic levels of food chain. Pollution monitoring, especially in the mangrove ecosystem is very strategic. This is premised on the menace orchestrated by this condition which has caused government and their agencies globally huge sums of money. While acting as a reservoir for the phyto-filtration and extraction of metals ${ }^{10}$, mangrove is also used as bio-indicators for heavy metal pollution.

However, their accumulation and subsequent distribution according to Guo et al. ${ }^{21}$ depend on various factors which include redox conditions and organic contents of the sediments in the ecosystem. These factors as also observed by Mason et al. ${ }^{22}$ which may influence the toxicity of metals through processes such as mercury methylation as well as controlling metals' availability for living organisms. It has been observed that metals can be absorbed onto the surface of minerals like clay, iron and/or manganese oxy-hydroxides, thus hindering their availability ${ }^{23,24}$.

The results showed that there were significant variations in the depositions and accumulation of these heavy metals in the mangrove sediments along the tidal levels. Among the heavy metals, iron deposition was highest in the sediments of $A$. africana in the high tide while cadmium and lead were in highest deposition in the $N$. fruticans sediment that was sampled in the low tide. However, in the mid tide $R$. racemosa sediment, copper was found to be high. The elevated concentration of iron in the high tidal level might probably be due to redox conditions in sedimentary columns and the relation of the iron in the organic fractions as well as in the water soluble and exchangeable fractions ${ }^{25-27}$. Undoubtedly, the extent of pollution in the mangrove ecosystem is proportional to anthropogenic disturbances of the mangrove due to the rate of urbanization and industrialization in the municipality ${ }^{7,8}$ and adjoining communities surrounding the mangrove. Such perturbations affect sediment properties as water currents, tidal flow and the ability of mangrove trees to capture sediments are altered ${ }^{28}$.

The current results on the accumulation of these heavy metals in mangrove tissues revealed that there were significant variations in their concentrations in the mangrove plants which indicated that the trend in the accumulation was roots $>$ barks $>$ leaves, the mangrove notwithstanding. The significant variation in the accumulation of heavy metals in the tissues of mangrove plants might be basically due to (a) The metal need of the specific tissues, (b) The amount/quantity of metals deposition in the sediments of the mangrove and (c) Sea water intrusion during high tide. Expectedly, besides the high deposition of these metals on the mangrove sediments, their accumulation was more in the roots than other plant tissues. The explanation probably is that the roots first receive the metals and depending on the need of the other tissues, roots supply. This alteration occasioned by the perturbation may as well affect the heavy metals that get deposited in the sediments of the different tidal levels where the different mangroves were sampled.

According to Alberts et al. ${ }^{20}$, metals such as chromium and lead, have low rates of translocation and as such are much more concentrated in the roots than in stems or leaves. Apart from copper whose concentration was higher in the leaves, concentrations of other metals 
were least in the leaves. This obviously suggests active translocation, transport and biomass production processes $^{29,30}$. This also suggests that copper can be sequestered from the leaves while monitoring copper pollution in the mangrove forest of Cross River Estuary. The Concentration Factor (CF) indicated that zinc was high in the soil for the plants to assimilate. Though this factor increases the risk of the metal entering into food chain, however, zinc is a micronutrients and its accumulation might not pose threat to the plant. The implication is that there is the possibility that a metal can be present in the soil but not available for plant to absorb or assimilate. This might be case of other heavy metals whose CF was not high.

The high CF of zinc, copper and manganese in the tissues of the mangrove plants across the tidal levels might suggest active uptake and possible storage of these metals needed for the plant growth and development. Bioavailability of metals and their transfer from soil to plants are affected by physicochemical parameters ${ }^{26,31,32}$. Although, the concentration of cadmium in the sediments was very high, CF in the mangrove species was low. This may be due to the high concentrations of other metal ions, especially zinc in the soil which had been reported to inhibit uptake of cadmium ${ }^{33}$. The low CF obtained for nickel and lead may be indications of lack of storage of these metals in plant tissues ${ }^{31}$. This might presuppose that there may be cadmium and lead pollution given the high presence of these metals.

The accumulation and the seeming tolerable and permissible limits of the heavy metals sampled except cadmium notwithstanding, the levels of these metals could obstruct the food chain of aquatic organisms inhibiting the mangrove. This was the positions of Kramer and Charonnems ${ }^{34}$; Zhou et al. ${ }^{35}$; Uzair et al. ${ }^{36}$. It should be understood that copper and zinc are micronutrients essential for plant growth, thus their concentrations in the leaves and barks may reflect physiological requirements of the mangroves. According to Wankassi et al. ${ }^{10}$, the shoot of mangrove trees may act as a good absorber for the remediation of metal ion polluted environments. Going by results of present study, the possibility of the leaves and barks of these mangrove species being used as copper sink might not be in contention. This low bioaccumulation of heavy metals in the mangrove leaves might indirectly imply also low accumulation of these metals in the tissue of organism in the ecosystem. This is premised on the fact that leaf litter constitutes major components of detrital food chain. Comparing heavy metals in sediments and plant tissues may be convenient for assessment of some measure of pollution, the limitations of this method, notwithstanding ${ }^{37}$. The ability of any plant to accumulate heavy metals in its tissues as well as its capacity to withstand heavy metal pollution is genetically controlled. Genetic engineering approach can be used for further studies to understand and enhance the phytoremediation properties of these mangroves ${ }^{38}$.

\section{CONCLUSION}

Although, the concentrations obtained for the heavy metals studied are generally below documented toxic levels, however, the increasing level of urbanization and industrialization in Calabar municipality and its environs calls for continuous vigilance, surveillance and monitoring of this sensitive and all important ecosystem to protect and ensure that heavy metal pollution is minimal.

\section{REFERENCES}

1. Hogarth, P.J., 1999. The Biology of Mangroves. Oxford University Press, Oxford, UK., ISBN-13: 9780198502234, Pages: 228.

2. Middleton, B.A. and K.L. McKee, 2001. Degradation of mangrove tissues and implications for peat formation in Belizean Island forests. J. Ecol., 89: 818-828.

3. Wafar, S., A.G. Untawale and M. Wafar, 1997. Litter fall and energy flux in a mangrove ecosystem. Estuarine Coastal Shelf Sci., 44: 111-124.

4. Clough, B., D.T. Tan, D.X. Phuong and D.C. Buu, 2000. Canopy leaf area index and litter fall in stands of the mangrove Rhizophora apiculata of different age in the Mekong Delta, Vietnam. Aquat. Bot., 66: 311-320.

5. Rate, A.W., A.E. Robertson and A.T. Borg, 2000. Distribution of heavy metals in near-shore sediments of the Swan River estuary, Western Australia. Water Air Soil Pollut., 124: 155-168.

6. Kairo, J.G., F. Dahdouh-Guebas, J. Bosire and N. Koedam, 2001. Restoration and management of mangrove systems-a lesson for and from the East African region. South Afr. J. Bot., 67: 383-389.

7. Pekey, H., 2006. Heavy metal pollution assessment in sediments of the Izmit Bay, Turkey. Envrion. Monit. Assess., 123: 219-231.

8. Ray, A.K., S.C. Tripathy, S. Patra and V.V. Sarma, 2006. Assessment of Godavari estuarine mangrove ecosystem through trace metal studies. Environ. Int., 32: 219-233. 
9. Mackey, A.P. and S. Mackay, 1996. Spatial distribution of acid-volatile sulphide concentration and metal bioavailability in mangrove sediments from the Brisbane River, Australia. Envrion. Pollut., 93: 205-209.

10. Wankasi, D., M. Horsfall Jr. and A.I. Spiff, 2006. Sorption kinetics of $\mathrm{Pb}^{2+}$ and $\mathrm{Cu}^{2+}$ ions from aqueous solution by Nipah palm (Nypa fruticans Wurmb) shoot biomass. Electron. J. Biotech., 9: 587-592.

11. Chindah, A.C., A.S. Braide and O.C. Sibeudu, 2004. Distribution of hydrocarbons and heavy metals in sediment and a crustacean (shrimpPenaeus notialis) from the Bonny/New Calabar River Estuary, Niger Delta. Afr. J. Environ. Assessment Manage., 9: 1-17.

12. Igwe, J.C., I.C. Nnororm and B.C.G. Gbaruko, 2005. Kinetics of radionuclides and heavy metals behaviour in soils: Implications for plant growth. Afr. J. Biotechnol., 4: 1541-1547.

13. Islam, M.O., H.R., Khan, A.K. Das, M.S. Akhtar, Y. Oki and T. Adochi, 2006. Impacts of industrial effluents on plant growth and soil properties. Soil Environ., 25: 113-118.

14. Mackey, A.P. and M.C. Hodgkinson, 1995. Concentrations and spatial distribution of trace metals in mangrove sediments from the Brisbane River, Australia. Environ. Pollut., 90: 181-186.

15. Clark, M.W., D. McConchie, D.W. Lewis and P. Saenger, 1998. Redox stratification and heavy metal partitioning in Avicennia-dominated mangrove sediments: A geochemical model. Chem. Geol., 149: 147-171.

16. Filip, Z., 2002. International approach to assessing soil quality by ecologically-related biological parameters. J. Agric. Ecosyst. Environ., 83: 169-174.

17. Ramasamy, M.S. and A. Murugan, 2002. Coral and Mangrove-Problems and Management Strategies. In: Proceedings of the National Seminar on Marine and Coastal Ecosystems Suganthi Davadanson Marine Research Institute (SDMRI), Edward, J.K.P., A. Murugan and J. Patterson (Eds.). Resource Publication, Ruticorin, India, pp: 181-184.

18. Allen, S.E., H.M. Grimshaw, J.A. Parkinson and C. Quarmby, 1974. Chemical Analysis of Ecological Materials. Blackwell Scientific Publications, Oxford, Pages: 565.

19. Turekian, K.K. and K.H. Wedepohl, 1961. Distribution of the elements in some major units of the earth's crust. Geol. Soc. Am. Bull., 72: 175-192.
20. Alberts, J.J., M.T. Price and M. Kania, 1990. Metal concentrations in tissues of Spartina alterniflora (Loisel.) and sediments of Georgia salt marshes. Estuarine Coastal Shelf Sci., 30: 47-58.

21. Guo, T., R.D. DeLaune and W.H. Patrick Jr., 1997. The influence of sediment redox chemistry on chemically active forms of arsenic, cadmium, chromium and zinc in estuarine sediment. Environ. Int., 23: 305-316.

22. Mason, R.P., W.F. Fitzgerald and F.F.M. Morel, 1994. The biogeochemical cycling of elemental mercury: Anthropogenic influences. Geochimica Cosmochimica Acta, 58: 3191-3198.

23. Quemerais, B., D. Cossa, B. Rondeau, T.T. Pham and B. Fortin, 1998. Mercury distribution in relation to iron and manganese in the waters of the St. Lawrence river. Sci. Total Environ., 213: 193-201.

24. Dong, D., Y.M. Nelson, L.W. Lion, M.L. Shuler and W.C. Ghiorse, 2000. Adsorption of Pb and Cd onto metal oxides and organic material in natural surface coatings as determined by selective extractions: New evidence for the importance of Mn and Fe oxides. Water Res., 34: 427-436.

25. Sundby, B., N. Silverberg and R. Chesselet, 1981. Pathways of manganese in an open estuarine system. Geochimiea Gosmochimiea Acta, 45: 293-307.

26. Izquierdo, C., J. Usero and I. Gracia, 1997. Speciation of heavy metals in sediments from salt marshes on the Southern Atlantic Coast of Spain Mar. Pollut. Bull., 34: 123-128.

27. Akpan, E., U. Ekpe and U. Ibok, 2002. Heavy metal trends in the Calabar river, Nigeria. Environ. Geol., 42: 47-51.

28. Kaly, U.L., G. Eugelink and A.I. Robertson, 1997. Soil conditions in damaged north Queensland mangroves. Estuaries, 20: 291-300.

29. Markert, B., 1993. Instrumental Analysis of Plants. In: Plants as Biomonitors: Indicators for Heavy Metals in the Terrestrial Environment, Markert, B. (Ed.). VCH Publishing, New York, USA., pp: 65-104.

30. Phillips, D.J.H., 1995. The chemistries and environmental fates of trace metals and organochlorines in aquatic ecosystems. Mar. Pollut. Bull., 31: 193-200.

31. Ross, S.M., 1994. Toxic Metals: Fate and Distribution in Contaminated Ecosystems. In: Soil-Plant Systems, Ross, S.M. (Ed.). John Wiley and Sons, Chichester, UK., pp: 189-235. 
32. Tam, M.F.Y. and Y.S. Wong, 1996. Mangrove soils as sinks for wastewater-borne pollutants. Hydrobiologia, 295: 231-241.

33. Thornton, I., 1981. Geochemical Aspects of the Distribution and Forms of Heavy Metals in Soils. In: Effect of Heavy Metal Pollution on Plants: Metals in the Environments, Lepp, N.W. (Ed.). Vol. 2, Springer, New York, USA., ISBN-13: 978-94-009-8099-0, pp: 1-33.

34. Kramer, U. and A.N. Chardonnens, 2001. The use of transgenic plants in the bioremediation of soils contaminated with trace elements. Applied Microbiol. Biotechnol., 55: 661-672.

35. Zhou, L., J. Vandersteen, L. Wang, T. Fuller, M. Taylor, B. Palais and G.T. Wittwer, 2004. High-resolution DNA melting curve analysis to establish HLA genotypic identity. Tissue Antigens, 64: 156-164.
36. Uzair, M., M. Ahmed and K. Nazim, 2009. Effect of industrial waste on seed bank and growth of wild plants in Dhabeji area, Karachi, Pakistan. Pak. J. Bot., 41: 1659-1665.

37. Fan, W. and W.X. Wang, 2001. Sediment geochemical controls on CD, CR and ZN assmilation by the clam Ruditapes philippinarum. Environ. Toxicol. Chem., 20: 2309-2317.

38. Fulekar, M.H., H. Singh and A.M. Bhaduri, 2009. Genetic engineering strategies for enhancing phytoremediation of heavy metals. Afr. J. Biotechnol., 8: 529-535. 